\title{
ACUTE ACQUIRED HAEMOLYTIC ANAEMIA ASSOCIATED WITH HERPES SIMPLEX INFECTION
}

BY

\author{
R. MCLAREN TODD and N. V. O'DONOHOE \\ From Alder Hey Children's Hospital, Liverpool
}

(RECEIVED FOR PUBLICATION JUNE 13, 1958)

Acquired haemolytic anaemia in childhood is a relatively uncommon condition. Lederer (1925) described three patients with acute haemolytic anaemia and in the literature up to 1938 Atkinson (1940) found 59 cases of 'Lederer's anaemia', 30 of which were in children. Millichap (1952) reviewed the papers published between 1940 and 1951 and found reports of a further 32 children with this disorder, the youngest patient affected being 6 weeks of age.

Acquired haemolytic anaemia may develop after treatment with drugs such as quinine, sulphonamides, para-amino-salicylic acid, or after chemical poisons, for example naphthalene, benzene; it may be associated with general diseases such as leukaemia, lymphadenoma, liver diseases, lupus erythematosus; it may follow or be associated with infections either caused by bacteria (Streptococcus; $\mathrm{Cl}$. welchii; $\mathrm{Cl}$.tetanis) or by viruses (virus pneumonia, influenza $A$, coxsackie $A$, infectious mononucleosis, Newcastle disease, measles); but it is frequently unassociated with any obvious disease although investigations may point to the presence of autoagglutinins or auto-haemolysins. Boorman, Dodd and Loutit (1946) considered that congenital and acquired haemolytic anaemias could be distinguished by the antiglobulin (Coombs) test which was thought to be positive only in acquired haemolytic anaemias; but Wright, Dodd, Bouroncle, Doan and Zollinger (1951) have shown that the Coombs test may be negative in acquired haemolytic anaemia and positive in the congenital type. The stimulus to production of the antibodies in this disorder remains a mystery in many cases but the most likely explanation is that the antigen is derived from infective agents such as bacteria or viruses. The clinical features and results of investigations in a patient recently under our care are now described.

\section{Case Report}

Ann O'D., aged 6 years 3 months, was admitted to Alder Hey Children's Hospital on February 2, 1957.
Two months before admission she had a clinically mild attack of measles and no complications developed. She returned to school and remained well until five days before admission when she was off colour and did not want to eat. Her family doctor found clinical evidence of a throat infection and prescribed oral penicillin. Her condition did not improve with this therapy and her parents noticed increasing pallor. On the day before admission she vomited once and gradually became semicomatose. No bleeding was observed from the gastro-intestinal tract or elsewhere.

Her mother, father, sister and three brothers were healthy and there was no family history of allergy, tuberculosis or other disease. When admitted to hospital she was in a semi-comatose condition, extremely pale and with a slight icteric tinge. Oral temperature was $99.8 \mathrm{~F}$., pulse rate 160 per minute, respirations 25 per minute, and sighing in character. No petechiae were present in the skin or mucous membranes, but a few bruises ('normal') were present on both shins. Oral examination showed that the gums were healthy but a few herpetic lesions were present on the inside of the cheeks. There were no signs of infection in the throat, ears, or lungs and no lymphatic glandular enlargement in the neck, axillae or groins. The heart was not enlarged but generalized haemic murmurs were heard, and the systolic blood pressure was $80 \mathrm{~mm}$. $\mathrm{Hg}$. The liver was palpable one finger breadth below the costal margin and the spleen was enlarged to two finger breadths below the costal margin. The optic fundi and general neurological examination did not reveal any abnormal signs.

The haemoglobin was $14 \%(2 \cdot 1 \mathrm{~g} . \%)$; white cells 2,600 per c.mm (neutrophils $58 \%$, lymphocytes $18 \%$, monocytes $15 \%$ ); the red cells showed spherocytosis and the platelets were present in normal numbers. Direct Coombs test was strongly positive. Total serum protein level was 5.9 g. $\%$, albumin 2.49 g. $(42.3 \%)$, globulin 3.41 g. $(57.7 \%), A / G$ ratio 0.73 to $1 ; \gamma$ globulin 1.50 g. $\%(25 \cdot 5 \%), \beta_{2} 0 \cdot 21$ g. $\%(3 \cdot 6 \%), \beta_{1} 0 \cdot 39$ g. $(6 \cdot 6 \%)$, $a_{2} 0.75 \mathrm{~g} . \%(12.6 \%)$ and $\alpha_{1} 0.56 \mathrm{~g} . \%(9.4 \%)$. These results show a $\gamma$ globulin level twice the normal, a slightly raised $\alpha_{1}$, and a lowered $\beta_{1}$. Paul Bunnell reaction was negative. Blood transfusion was started on admission, and a total of two pints of packed red cells and one pint of blood was given over a period of 26 hours. 
A.C.T.H. was given intramuscularly in a dosage of 80 units twice daily for five days, followed by prednisolone $15 \mathrm{mg}$. three times daily for five days, reducing by $5 \mathrm{mg}$. every two days and discontinued four weeks after admission. Progress has been satisfactory and hepatosplenomegaly gradually subsided over a period of 10 months. Table 1 shows the results of serial blood investigations.

TABLE 1

SERIAL BLOOD INVESTIGATIONS

\begin{tabular}{|c|c|c|c|c|c|}
\hline Date & $(\text { g. } \%)^{\mathrm{H}}$ & $(\%)$ & $\begin{array}{c}\text { W.B.C. } \\
\text { (per c.mm.) }\end{array}$ & $\underset{(\%)}{\text { Reticulocytes }}$ & $\begin{array}{l}\text { Direct } \\
\text { Coombs }\end{array}$ \\
\hline $\begin{array}{c}2.2 .57 \\
6 \\
12 \\
20 \\
25 \\
6.3 .57 \\
14 \\
28 \\
11.4 .57 \\
16 \\
9.5 .57 \\
23 \\
20.6 .57 \\
25.7 .57 \\
5.9 .57 \\
29.11 .57 \\
11.3 .58\end{array}$ & $\begin{array}{r}2 \cdot 1 \\
9 \cdot 2 \\
8 \cdot 9 \\
11 \cdot 8 \\
13 \cdot 3 \\
13 \cdot 3 \\
10 \cdot 4 \\
11 \cdot 8 \\
12 \cdot 3 \\
12 \cdot 3 \\
11.5 \\
10 \cdot 4 \\
10.9 \\
11.7 \\
11.4\end{array}$ & $\begin{array}{l}14 \\
62 \\
60 \\
\\
80 \\
90 \\
90 \\
70 \\
80 \\
83 \\
83 \\
78 \\
70 \\
74 \\
79 \\
77\end{array}$ & $\begin{array}{r}2,600 \\
11,000\end{array}$ & $\stackrel{12}{2 \cdot 3}$ & 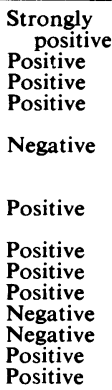 \\
\hline
\end{tabular}

Virus studies gave the following results:

Complement fixation tests negative for mumps and L.C.M. positive for recent herpes simplex infection.

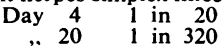

$$
\begin{aligned}
& \text { Neutralization tests herpes simplex } \\
& \text { Day } 4 \text { positive } 1 \text { in } 16 \\
& \text { negative } 1 \text { in } 32 \\
& \text {, } 20 \text { positive } 1 \text { in } 256 \\
& \text { (only taken to this dilution) }
\end{aligned}
$$

We failed to isolate any agent from this child's blood by inoculation of chorio-allantoic membrane of fertile hen's eggs and passage of these membranes after three days' incubation of primary eggs at $36^{\circ} \mathrm{C}$. Serum still had a titre of greater than 1 in 256 in the egg neutralization test.

During the past five years, four other patients with acute acquired haemolytic anaemia have been admitted to Alder Hey Children's Hospital, and Table 2 summarizes the relevant features.

\section{Discussion}

The onset of acute acquired haemolytic anaemia is often dramatic and treatment by blood transfusion to restore the haemoglobin level to a more normal value is an urgent matter. In our patient, the initial haemoglobin reading was $14 \%$ and in the four other patients seen in this hospital the haemoglobin levels reached $17 \%, 22 \%, 31 \%$ and $40 \%$ (Table 2 ); in Millichap's (1952) five patients haemoglobin levels varied from $18 \%$ to $48 \%$, and in the four patients reported by Rose and Nabarro (1953) haemoglobin levels varied from $12 \%$ to $28 \%$. A satisfactory response to blood transfusion is usually as dramatic as the onset of the illness but sometimes transfusion makes the situation worse because the transfused blood is haemolyzed rapidly. In these circumstances a replacement transfusion has proved of considerable value (Bowman, 1955), for this procedure removes antibody attached to the red cells and free in the plasma, and the fresh blood dilutes any free antibody that might remain in the circulating blood. Among the 21 children suffering from acute haemolytic anaemia reported between 1940 and 1950 (Millichap, 1952) $18(85 \%$ ) responded to blood transfusions alone. Steroid therapy is a useful adjunct to blood transfusion and probably acts by interrupting the antigen-antibody reaction, thus leading to a fall of antibody and hence to a lessening of the haemolytic process. In idiopathic acquired haemolytic anaemia, the basic disorder appears to be the patient's ability to form antibodies which have an affinity for the red blood cells. It is thought that antibodies are contained in the $\gamma$ globulin fraction of the plasma and it is of interest that in our patient the $\gamma$ globulin level was twice the normal value. These antibodies are usually pan-antibodies, i.e. they attack all human red cells, irrespective of blood group but elution of the red cells of our patient yielded anti-e. Weiner, Battey, Cleghorn, Marson and Meynell (1953) have described a man of 32 years with acute haemolytic anaemia in whom the antibody was also anti-e. Dacie (1954) has found that auto-antibodies in idiopathic haemolytic anaemia are of two main kinds, warm and cold. $\mathrm{He}$ reported the presence of warm antibodies in

\begin{tabular}{|c|c|c|c|c|c|c|c|}
\hline Case & Age & $\begin{array}{l}\text { Duration of } \\
\text { Symptoms } \\
\text { Before } \\
\text { Admission }\end{array}$ & $\underset{\text { Admission }}{\text { On }}$ & $\begin{array}{l}\text { Lowest } \\
\text { Level }\end{array}$ & $\stackrel{\text { Plasma }}{\text { Methaemalbumin }}$ & Direct Coombs & $\begin{array}{c}\text { Coombs Test } \\
\text { Negative } \\
\text { After: }\end{array}$ \\
\hline $\begin{array}{l}\text { J.W } \\
\text { H.W. } \\
\text { K. McD. } \\
\text { E.R. }\end{array}$ & $\begin{array}{rl}6 & \mathrm{~m} . \\
1 & \mathrm{yr} .7 \mathrm{~m} . \\
2 & \mathrm{yr} .2 \mathrm{~m} . \\
12 & \mathrm{yr} .\end{array}$ & $\begin{array}{ll}6 & \mathrm{~d} . \\
6 & \mathrm{w} . \\
3 & \mathrm{w} . \\
2 & \mathrm{w} .\end{array}$ & $\begin{array}{l}22 \\
40 \\
48 \\
52\end{array}$ & $\begin{array}{l}22 \\
40 \\
31 \\
17\end{array}$ & $\begin{array}{l}+ \\
+ \\
+\end{array}$ & $\begin{array}{l}- \\
+ \\
+ \\
+\end{array}$ & $\begin{array}{r}18 \mathrm{~m} . \\
8 \mathrm{w} . \\
6 \mathrm{w} .\end{array}$ \\
\hline
\end{tabular}
30 patients and cold antibodies in eight patients with acute haemolytic anaemia; in seven of these

TABLE 2

FEATURES OF FOUR PATIENTS WITH ACUTE ACQUIRED HAEMOLYTIC ANAEMIA

* Died after 5 days. Post mortem examination showed renal cortical necrosis. 
the illness followed virus pneumonia and in one measles preceded the anaemia.

Infections often precede the development of these acute anaemias and it is reasonable to suppose that the blood in its circulation through virus-infected tissue becomes contaminated with virus particles which are adsorbed on to the red cell surfaces; these virus-contaminated red blood cells may stimulate the reticulo-endothelial system to produce antibodies which destroy the red blood cells and also lead to a rising blood antibody titre. In eight patients with idiopathic haemolytic anaemia reported by Morgan (1955), tests for Newcastle disease virus, influenza, mumps, psittacosis, herpes and pox virus were negative; in the four children reported by Rose and Nabarro (1953) tests for influenza, glandular fever and psittacosis were negative. Moolten and Clark (1952) isolated Newcastle disease virus from the blood of a baby of 11 months and a patient of 37 years suffering from acute idiopathic haemolytic anaemia, and they also found an unidentified virus in the blood of 10 patients with acute haemolytic anaemia associated with general diseases such as leukaemia, Hodgkin's disease, lupus erythematosus, and infective hepatitis. Although we were unable to isolate a virus from the blood of our patient, the results of complement fixation and neutralization tests confirmed that a recent primary infection with herpes simplex virus had occurred. McNair Scott (personal communication) does not know of a report of a similar case, and we have been unable to find a similar example of the development of haemolytic anaemia following herpes simplex infection in the British or American literature.

\section{Summary}

The clinical features and results of haematological investigations of a girl of 6 years suffering from acute acquired haemolytic anaemia are recorded. Investigations suggest that the anaemia was the result of a recent primary infection with herpes simplex virus.

\section{REFERENCES}

Atkinson, F. R. B. (1940). Brit. J. Child Dis., 37, 35.

Boorman, K. E., Dodd, B. E. and Loutit, J. F. (1946). Lancet, 1, 812. Bowman, J. M. (1955). A.M.A. Amer J. Dis. Child., 89, 226.

Dacie, J. V. (1954). Sang, 25, 675.

Lederer, M. (1925). Amer. J. med. Sci., 170, 500.

McNair Scott, T. F. (1958). Personal communication.

Millichap, J. G. (1952). Arch. Dis. Childh., 27, 222.

Millichap, J. G. (1952). Arch. Dis. Childh., 27, 222.

Morgan, H. R. (1955). J. Lab. clin. Med., 46, 580

Rose. B. S. and Nabarro, S. N. (1953). Arch. Dis. Childh., 28, 87.

Wright, C. S., Dodd, M. C., Bouroncle, B E., Doan, C. A. and Zollinger, R. M. (1951). J. Lab. clin. Med., 37, 165.

Weiner, W., Battey, D. A., Cleghorn, T. E., Marson, F. G. W. and Meynell, M. J. (1953). Brit. med. J. 2, 125. 